\title{
Standardisasi Laboratorium IPA SMPN 3 Sumenep
}

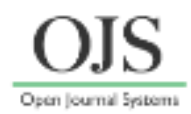

\author{
Nisfil Maghfiroh Meita \\ FKIP Universitas Wiraraja, Madura \\ Email: nisfil@wiraraja.ac.id
}

\begin{abstract}
[Standardization of science laboratory at SMPN 3 Sumenep]. Schools must have laboratory infrastructure in addition to other educational equipment and tools. Therefore, students can construct thinking from the concrete towards abstract thinking. To get a good laboratory, a standardized laboratory is needed in accordance with national education standards in Indonesia, especially standard facilities and infrastructure. The objectives of this research were to describe 1) the science laboratory equipment of SMPN 3 Sumenep; 2) science laboratory management of SMPN 3 Sumenep; and 3) suitability of the standardization of the science laboratory of SMPN 3 Sumenep with Indonesian government regulation of PERMEN No. 24, 2007. The subject of the research is SMPN 3 Sumenep. This research is a qualitative descriptive study. Data collection techniques use interviews, observation, and document scrutiny. The instrument used was an observation instrument with a Guttman scale. Data validity test is done by triangulating data sources. Data were analyzed using models from Miles and Huberman with the stages of data collection, data reduction, data presentation, and conclusion drawing. The results showed that 1) Science laboratory equipment at Sumenep Junior High School 3 had a percentage of $86.34 \%$ with good / ideal criteria and in accordance with the standardization of PERMEN No. 24 of 2007; 2) Management of science labs at Sumenep Junior High School 3; and 3) Science Laboratory of SMPN 3 Sumenep is a good / ideal laboratory for SMP Science Laboratory and has fulfilled standardization based on PERMEN No. 24 of 2007.
\end{abstract}

Keywords: Standardization; Science Laboratory; Indonesian government regulation.

\begin{abstract}
ABSTRAK
Sekolah harus memiliki sarana prasarana laboratorium disamping perabot dan peralatan pendidikan lainnya. Sehingga siswa dapat mengkonstruk pemikiran dari yang konkrit menuju ke pemikiran abstrak. Untuk mendapatkan laboratorium yang baik maka diperlukan laboratorium berstandardisasi yang sesuai dengan standar nasional pendidikan di Indonesia khususnya standar sarana dan prasarana. Tujuan penelitian yang kami lakukan adalah untuk 1) mengetahui perlengkapan laboratorium IPA SMPN 3 Sumenep; 2) mengetahui manajemen laboratorium IPA SMPN 3 Sumenep; dan 3) mengetahui kesesuaian standardisasi laboratorium IPA SMPN 3 Sumenep dengan PERMEN No. 24 tahun 2007. Subjek penelitian merupakan Sekolah Menengah Pertama Negeri 3 Sumenep. Penelitian ini merupakan penelitian deskriptif kualitatif. Teknik pengumpulan data menggunakan wawancara, observasi, dan pencermatan dokumen. Instrumen yang digunakan adalah instrumen observasi dengan skala Guttman. Uji keabsahan data dilakukan dengan triangulasi sumber data. Data dianalisis dengan menggunakan model dari Miles dan Huberman dengan tahapan pengumpulan data, reduksi data, penyajian data, dan penarikan kesimpulan. Hasil penelitian menunjukkan bahwa 1) Perlengkapan laboratorium IPA SMPN 3 Sumenep memiliki persentase 86,34\% dengan kriteria baik/ ideal dan sesuai dengan standardisasi PERMEN No. 24 tahun 2007; 2) Manajemen laboratorium IPA SMPN 3 Sumenep baik; dan 3) Laboratorium IPA SMPN 3 Sumenep merupakan laboratorium yang baik/ ideal untuk Laboratorium IPA SMP serta sudah memenuhi standardisasi berdasarkan PERMEN No. 24 tahun 2007.
\end{abstract}

Kata Kunci: Standardisasi; Laboratorium IPA; Peraturan Pemerintah RI. 


\section{PENDAHULUAN}

Badan Standar Nasional Pendidikan (BSNP, 2010) menyatakan bahwa Kebutuhan paling dasar dalam proses pembelajaran pada jenjang pendidikan dasar adalah ruang kelas dan perpustakaan dan pada jenjang pendidikan menengah ditambah dengan ruang laboratorium. Kegiatan laboratorium akan sangat mendukung pelaksanaan proses pembelajaran IPA, terutama karena Ilmu Pengetahuan Alam dibangun dari berbagai eksperimen. Disamping merupakan salah satu aspek penilaian penjaminan mutu pendidikan nasional (PP No. 19 Tahun 2005), pentingnya praktikum dalam pendidikan IPA juga mensyaratkan bahwa keberadaan laboratorium IPA di SMP benar-benar penting. PP Nomor 19 Tahun 2005 mensyaratkan bahwa pendidikan wajib memiliki prasarana termasuk ruang laboratorium untuk menunjang proses pembelajaran yang teratur dan berkelanjutan.

Laboratorium merupakan salah satu sarana pendidikan yang menunjang kegiatan pembelajaran siswa khususnya dalam melakukan eksperimen. Darsana, dkk (2014) mendeskripsikan bahwa laboratorium dalam proses pembelajaran digunakan untuk mencapai berbagai tujuan. Tujuan kognitif berhubungan dengan belajar konsep-konsep ilmiah, proses pengembangan keterampilan, dan meningkatkan pemahaman tentang metode ilmiah. Tujuan-tujuan praktis (psikomotor) berhubungan dengan pengembangan ketrampilan-ketrampilan dalam melakukan pelatihan IPA, analisis data, berkomunikasi dan keterampilan-keterampilan dalam bekerjasama antar kelompok. Tujuan afektif berhubungan dengan motivasi terhadap sains, tanggapan dan kemampuan dalam memahami lingkungan sekitar. Dengan adanya laboratorium diharapkan pikiran siswa dapat terancang dengan baik dan siswa dapat membangun pemahamannya dengan ide-ide. Pemahaman ini tidak hanya dapat langsung ditransfer oleh guru melainkan ditemukan sendiri oleh siswa.

Sumarjono (1999), ada beberapa faktor yang perlu diperhatikan jika ingin membuat laboratorium IPA, faktor-faktor tersebut antara lain: 1) Faktor Limbah; 2) Faktor Keamanan dan Kenyamanan; 3) Faktor Sumber Listrik PLN; dan 4) Faktor Sumber Air. Kelengkapan Ruang Laboratorium IPA yaitu ruang laboratorium IPA berfungsi sebagai tempat berlangsungnya kegiatan pembelajaran IPA secara praktek yang memerlukan peralatan khusus. Ruang laboratorium IPA dapat menampung minimum satu rombonganbelajar. Rasio minimum ruang laboratorium IPA 2,4 $\mathrm{m}^{2} /$ peserta didik. Untuk rombongan belajar dengan peserta didik kurang dari 20 orang, luas minimum ruang laboratorium $48 \mathrm{~m}^{2}$ termasuk luas ruang penyimpanan dan persiapan $18 \mathrm{~m}^{2}$. Lebar ruang laboratorium IPA minimum $5 \mathrm{~m}$. Ruang laboratorium IPA memiliki fasilitas yang memungkinkan pencahayaan memadai untuk membaca buku dan mengamati obyek percobaan. Ruang laboratorium IPA dilengkapi sarana sebagaimana tercantum pada PERMEN No 24 Tahun 2007. Laboratorium IPA harus dilengkapi dengan struktur organisasi sehingga pengelolaan/ manajemen sarana dan prasarana terlaksana sesuai dengan kebijakan yang telah disepakati dalam struktur organisasi. Sergiovani dalam Bafadal (2009: 1) menjabarkan bahwa manajemen merupakan proses pendayagunaan semua sumber daya dalam rangka mencapai tujuan yang telah ditetapkan. Pendayagunaan melalui tahapan proses yang meliputi perencanaan, pengorganisasian, pengarahan, dan pengawasan. G.R.Terry dalam bukunya berjudul "Principles Of Management" yang diterjemahkan oleh Mulyono (2008) membagi fungsi-fungsi manajemen itu atas empat fungsi yang lebih dikenal dengan istilah POAC, yaitu: 1) planning (perencanaan); 2) organizing (pengorganisasian); 3) actuating (pelaksanaan); dan 4) controlling (pengawasan). Tujuan penelitian adalah 1) mengetahui perlengkapan laboratorium IPA SMPN 3 Sumenep; 2) mengetahui manajemen laboratorium IPA SMPN 3 Sumenep; dan 3) mengetahui kesesuaian standardisasi laboratorium IPA SMPN 3 Sumenep dengan PERMEN No. 24 tahun 2007.

\section{METODE PENELITIAN}

Metode dalam penelitian ini merupakan penelitian deskriptif dengan menggunakan pendekatan kualitatif. Penelitian ini akan menggali informasi Standardisasi Laboratorium IPA SMPN 3 Sumenep. Teknik pengumpulan data yang digunakan dalam penelitian ini dilakukan dengan tiga cara yaitu wawancara, observasi, dan studi dokumentasi. Tahapan penelitian dalam penelitian ini dapat 
dilihat pada gambar 1 (Miles dan Huberman dalam Satori dan Komariah, 2009: 39).

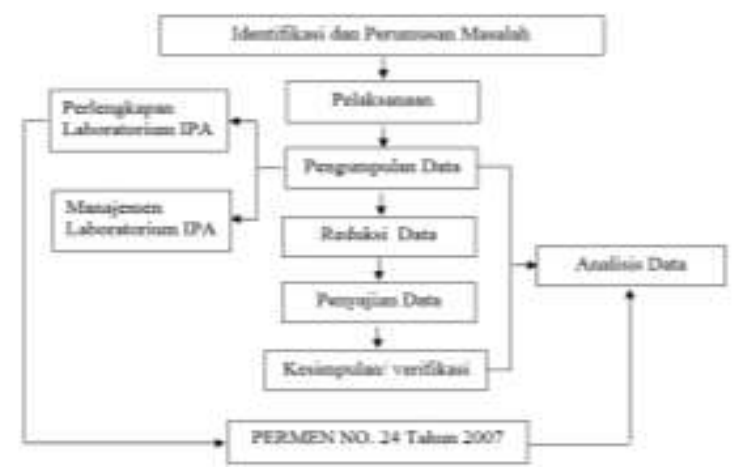

Gambar 1. Diagram Tahapan Penelitian

Analisis data penelitian kualitatif peneliti sependapat dengan langkah yang ditempuh oleh Miles dan Huberman dalam Satori dan Komariah (2009: 39) yaitu ada empat tahap atau langkah dalam analisis data penelitian kualitatif, antara lain:

1. Tahap pengumpulan data, yaitu proses memasuki lingkungan penelitian dan melakukan pengumpulan data penelitian. Lembar pengamatan menggunakan skala Guttman, analisis pada instrumen menerapkan analisis data proporsi (persentase). Hasil yang diperoleh dihitung dengan menggunakan persamaan sebagai berikut :

$$
S=\frac{R}{N} \times 100 \%
$$

(Rumus 1)

Sumber: (Istiqomah \& Kusumaningtyas,

2016)

dengan:

$\mathrm{S}=$ nilai yang diharapkan $(\%)$

$\mathrm{R}=$ jumlah skor dari item yang dijawab

$\mathrm{N}=$ skor maksimum dari instrumen

2. Tahap reduksi data, yaitu proses pemilihan, pemusatan perhatian pada penyederhanaan, pengabstrakan, dan transformasi data kasar yang muncul dari catatan-catatan tertulis di lapangan.

3. Tahap penyajian data, yaitu penyajian informasi untuk memberikan kemungkinan adanya penarikan kesimpulan dan pengambilan tindakan.

4. Tahap penarikan kesimpulan/verifikasi, yaitu penarikan kesimpulan dari data yang telah dianalisis. Hasil data kuantitatif diubah menjadi kategori kualitas dengan persentase pada Tabel 1 .

Tabel 1. Interpretasi Persentase

\begin{tabular}{lll}
\hline Persentase & Nilai & Kategori \\
\hline $51 \%<\mathrm{S} \leq 100 \%$ & Baik & Ideal \\
\hline $0 \%<\mathrm{S} \leq 50 \%$ & Tidak baik & Tidak ideal \\
\hline \multicolumn{3}{l}{ Sumber: (Istiqomah \& Kusumaningtyas, 2016) }
\end{tabular}

\section{HASIL DAN PEMBAHASAN}

\section{Hasil}

Perlengkapan Laboratorium IPA SMPN 3

Sumenep

Hasil observasi dengan menggunakan instrumen ketiga, jenis-jenis perabot laboratorium IPA SMPN 3 Sumenep memenuhi $100 \%$ standardisasi PERMEN No. 24 tahun 2007. Jenis perabot Laboratorium IPA (PERMEN No 24 Tahun 2007) terdiri dari kursi; meja peserta didik, meja demonstrasi; meja persiapan, lemari alat, lemari bahan; dan bak cuci. Kondisi perabot Laboratorium IPA SMPN 3 Sumenep dapat dilihat pada Tabel 2.

Tabel 2. Perabot Laboratorium IPA SMPN 3 Sumenep

\begin{tabular}{l|l|l|}
\hline \multicolumn{1}{c}{ Jenis } & \multicolumn{2}{c}{ Gambar } \\
\hline $\begin{array}{l}\text { Kursi; Meja } \\
\text { peserta didik; } \\
\text { Meja } \\
\text { demonstrasi } \\
\text { Meja } \\
\text { persiapan }\end{array}$ \\
\hline Lemari bahan
\end{tabular}

Peralatan pendidikan yang mengacu pada PERMEN No. 24 tahun 2007, pada laboratorium SMP minimum harus memiliki 41 buah peralatan. Laboratorium IPA SMPN 3 
Sumenep dari 41 buah peralatan hanya 6 peralatan yang tidak memenuhi. Peralatan yang tidak ada yaitu rol meter, batang magnet, cawan penguapan, plat tetes, poster genetika, dan gambar/ model sistem pernapasan manusia. Sehingga dapat diketahui bahwa 35 peralatan dari 41 peralatan yang harus tersedia di laboratorium IPA dengan persentase 85,36\% telah memenuhi standardisasi dari PERMEN No. 24 tahun 2007.

Media pendidikan laboratorium IPA berdasarkan PERMEN No 24 Tahun 2007 adalah papan tulis, SMPN 3 Sumenep telah menyediakan papan tulis yang dapat digunakan dalam pembelajaran saat di laboratorium. PERMEN No 24 Tahun 2007 mendeskripsikan dengan jelas perlengkapan lain yang harus ada di laboratorium SMP, perlengkapan yang diperlukan adalah soket listrik, alat pemadam kebakaran, peralatan P3K, tempat sampah, dan jam dinding. Soket listrik yang tersedia untuk peserta didik sangat memadai, jika peralatan percobaan membutuhkan sumber listrik soket listrik sangat dekat dengan meja peserta didik. Jumlah soket listrik adalah 1 untuk tiap 1 meja peserta didik. Rasio soket listrik dalam PERMEN No 24 Tahun 2007 adalah 9 buah untuk tiap laboratorium, di SMPN 3 Sumenep jumlah soket listrik di laboratorium adalah 10 buah di meja peserta didik dan ditambah dengan 1 soket listrik di dekat meja demonstrasi. Peralatan pemadam kebakaran pada tabel 3 tersedia dalam Laboratorium IPA SMPN 3 Sumenep, namun kondisi alat pemadam kebakaran tersebut sudah tidak bisa digunakan. Sehingga alat pemadam kebakaran tersebut hanya menjadi pajangan di ruang gudang laboratorium. Perlengkapan lain yang menjadi pajangan adalah kotak P3K yang kondisinya kosong tidak berisii perlengkapan untuk pengobaan jika terjadi kecelakaan percobaan di laboratorium. Hal ini terjadi dikarenakan di SMPN 3 Sumenep sudah memiliki UKS sehingga peralatan P3K di laboratorium tidak dilengkapi. Tempat sampah dan jam dinding menjadi keharusan yang seharusnya ada di laboratorium IPA berdasarkan PERMEN No 24 Tahun 2007, namun dua perlengkapan tersebut tidak tersedia di Laboratorium IPA SMPN 3 Sumenep.

Tabel 3 menunjukkan media pendidikan dan perlengakapan yang ada di Laboratorium IPA SMPN 3 Sumenep. Media pendidikan memenuhi standardisasi labora- torium sebesar $100 \%$. sedangkan persentase perlengkapan laboratorium memenuhi 60\% dari standardisasi PERMEN No. 24 tahun 2007. Dari media pendidikan dan perlengkapan lainnya diperoleh persentase rata-rata sebesar $80 \%$, artinya media pendidikan dan perlengkapan lain laboratorium IPA SMPN 3 Sumenep baik/ ideal (Istiqomah \& Kusumaningtyas, 2016).

Tabel 3. Media Pendidikan dan Perlengkapan Laboratorium IPA SMPN 3 Sumenep

\begin{tabular}{l}
\multicolumn{1}{c}{ Jenis } \\
$\begin{array}{l}\text { Media } \\
\text { Pendidikan: } \\
\text { Papan Tulis }\end{array}$ \\
\hline $\begin{array}{l}\text { Perlengka- } \\
\text { pan Lain: } \\
\text { Soket listrik }\end{array}$ \\
\hline $\begin{array}{l}\text { Alat pemadam } \\
\text { kebakaran \& } \\
\text { Peralatan P3K }\end{array}$ \\
\hline
\end{tabular}

\section{Manajemen Laboratorium IPA SMPN 3 Sumenep}

Struktur organisasi laboratorium terdiri dari: kepala sekolah, wakil kepala sekolah, tata usaha, guru IPA (pengelolah atau pembimbing), dan laboran. Bentuk struktur organisasi laboratorium IPA SMPN 3 Sumenep terdapat pada Gambar 2.

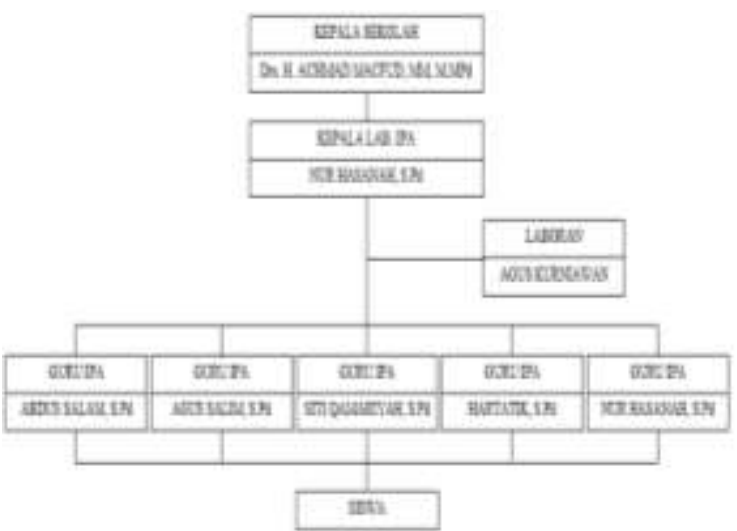

Gambar 2. Struktur Organisasi Laboratorium IPA SMPN 3 Sumenep

Hasil wawancara pada salah satu guru IPA di SMPN 3 Sumenep, diketahui bahwa tugas pengelola/ guru IPA pada kegiatan laboratorium diantaranya, (1) mengatur jadwal 
penggunaan laboratorium; (2) menyusun dan mengawasi tata tertib kerja di laboratorium; dan (3) mempertahankan dan memelihara suasana kerja yang berdisiplin.

Kegiatan administrasi umum yang dilakukan di SMPN 3 Sumenep meliputi halhal sebagai berikut: 1) Menyusun jadwal pemakaian laboratorium untuk kegiatan dengan memperhatikan data jumlah kelompok praktikum, waktu praktikum yang diminta, jenis praktikum atau demonstrasi, dan jumlah praktikum atau demonstrasi; 2) Pengarsipan yang dilakukan adalah: penyimpanan berkas tata tertib labortorium dan penyimpanan berkas jadwal kegiatan/ pemakaian laboratorium; dan 3) Keuangan di Laboratorium memanfaatkan dana swadaya/ kas kelas siswa untuk bahan habis pakai, pengusulan alat baru bekerja sama dengan instansi pemerintah, keuangan untuk alat rusak akibat kelalaian peserta didik menjadi tanggung jawab perusak alat, dan keuangan untuk alat rusak yang tidak disebabkan oleh peserta didik menjadi tanggung jawab sekolah.

Kegiatan administrasi khusus yang dilakukan di SMPN 3 Sumenep meliputi halhal sebagai berikut: 1) Inventarisasi alat praktikum/peraga/perlengkapan labortorium. Data inventaris disimpan dalam bentuk soft file, sedangkan hard file ada di laboratorium dan kepala laboratorium IPA; 2) Pengaturan penyimpanan alat-alat disesuaikan dengan nama-nama barang yang tertera dalam daftar barang di depan lemari. Bagi alat yang cepat rusak karena debu, maka disimpan dalam lemari kayu yang berdaun pintu terbuat dari kaca seperti pada model kerangka manusia dan model tubuh manusia; 3) Perawatan dan perbaikkan alat yang rusak ringan, akan direparasi sendiri oleh laboran/teknisi. Jika kerusakannya berat, maka akan direparasikan pada tukang reparasi; 4) Pelayanan kegiatan praktikum/ tugas laboran bersama guru pembimbing praktikum, antara lain: Mempersiapkan alat- alat/bahan- bahan yang dibutuhkan untuk setiap unit minimal 1 hari sebelum hari pelaksanaan praktikum. Setiap alat atau bahan yang akan digunakan dalam praktikum dicatat dalam Daftar Penggunaan Alat/ Bahan Praktikum. Jika tidak air, laboran segera mencari alternatif sehingga dapat diperoleh air. Penyaluran arus listrik harus memenuhi ketentuan PLN; 5) Faktor pengadaan alat dan bahan praktikum, antara lain: faktor dana/biaya, kurikulum yang berlaku, macam percobaan, jenis dan ukuran alat, dan persediaan alat/bahan yang masih ada. Pengusulan pengadaan alat dan bahan dlakukan oleh pengelola laboratorium. Alat/bahan yang diusulkan diajukan oleh guru IPA, yang kemudian diajukan ke Kepala Sekolah untuk meminta persetujuannya.

\section{Pembahasan}

Perlengkapan Laboratorium IPA SMPN 3 Sumenep

Tabel 4. Persentase Perlengkapan

Laboratorium IPA SMPN 3 Sumenep

\begin{tabular}{lcc}
\hline \multicolumn{1}{c}{ Kategori } & $\begin{array}{c}\text { Persen } \\
\text { tase }\end{array}$ & Kriteria \\
\hline 1. Perabot & 100 & baik/ideal \\
\hline 2. Peralatan & 85,36 & baik/ideal \\
\hline 3. Media & 100 & baik/ideal \\
\hline $\begin{array}{l}\text { 4. Perlengkapan } \\
\text { lainnya }\end{array}$ & 60 & baik/ideal \\
\hline Rata-rata & $\mathbf{8 6 , 3 4}$ & baik/ideal \\
\hline
\end{tabular}

Tabel 4. menunjukkan bahwa perlengkapan laboratorium IPA SMPN 3 Sumenep meliputi kategori perabot, peralatan, media pendidikan, dan perlengkapan lainnya. Ratarata persentase perlengkapan laboratorium IPA SMPN 3 Sumenep sebesar 86,34\% dengan kriteria baik/ ideal (Istiqomah dan Kusumaningtyas, 2016) dan sesuai dengan standardisasi PERMEN No. 24 tahun 2007.

Perabot meliputi meja, kursi, lemari alat dan bahan, serta bak cuci. Keseluruhan perabot dalam Laboratorium IPA SMPN 3 Sumenep berdasarkan hasil observasi sudah lengkap dan sesuai dengan rasio PERMEN No. 24 tahun 2007, dengan rincian sebagai berikut: 1) Kursi peserta didik dan guru sudah diperhitungkan sesuai dengan jumlah peserta didik dan guru; 2) Meja peserta didik dapat digunakan maksimal 7 peserta didik dalam 1 meja; 3) Meja demonstrasi terbuat dari kayu, berbentuk persegi panjang, dan terletak di depan sehingga dapat digunakan sesuai dengan fungsinya; 4) Meja persiapan tidak seperti meja demostrasi yang terbuat dari kayu, meja persiapan memanfaatkan bangunan laboratorium yang bentuknya menyerupai meja. Perabot selain meja dan kursi di Laboratorium IPA SMPN 3 Sumenep yaitu 1) Lemari alat dalam ada yang terbuat dari kaca dan kayu. Lemari alat digunakan untuk menyimpan alat, di luar lemari disediakan daftar nama alat-alat yang ada di dalamnya sesuai dengan kode barang, 
jumlah dan kondisi alat. Namun tidak semuanya alat-alat di Laboratorium IPA SMPN 3 Sumenep memiliki kode barang; 2) Lemari bahan sudah digunakan untuk menyimpan bahan-bahan percobaan yang akan amaupun yang sudah digunakan. Bahan dan alat percobaan disimpan dilemari terpisah, namun kekurangannya adalah nama-nama bahan tidak tersedia seperti nama alat. Budiati dalam (Senta, 2014) menjabarkan tentang penyusunan peralatan dan bahan harus teridentifikasi secara baik. Tempat peralatan (lemari) harus dilengkapi dengan daftar alat yang akan disimpan di dalamnya, setiap wadah bahan kimia harus dilengkapi dengan label karakteristik bahan, penempatan bahan harus terklasifikasi sesuai tingkat bahayanya dan rak penyimpanan bahan dilengkapi dengan label tanda bahaya; 3) Bak cuci sudah tersedia, namun bak cuci pada Laboratorium IPA SMPN 3 Sumenep tidak bisa digunakan sesuai dengan fungsinya yang disebabkan karena aliran air yang mati.

Media pendidikan memenuhi standardisasi laboratorium sebesar $100 \%$, media pendidikan yang dimaksud adalah papan tulis. Yuliarty dkk (2008) menjelaskan bahwa keberadaan papan tulis merupakan benda yang sangat penting dalam proses belajar mengajar yang salah satu fungsinya adalah sebagai media menuliskan materi pembelajaran. Di Laboratorium SMPN 3 Sumenep papan tulis didesain untuk memiliki dwifungsi, yaitu selain sebagai media menulis pada sepertiga bagian papan tulis ditempeli karpet yang berguna untuk menempelkan poster baik dengan plester/ doubletapel pin (jarum). Sehingga papan tulis berfungsi dengan maksimal.

\section{Manajemen Laboratorium IPA SMPN 3 Sumenep}

Mulyono (2008) membagi fungsi-fungsi manajemen itu atas empat fungsi yang lebih dikenal dengan istilah POAC, yaitu: 1) planning (perencanaan) dilakukan oleh guru pengelola/ guru IPA di SMPN 3 Sumenep. Dalam hal perencanaan yang merupakan unsur awal manajemen, pihak pengelola laboratorium IPA SMPN 3 Sumenep telah melaksanakan kegiatan-kegiatan sebagaimana menurut Arikunto dan Yuliana, yaitu: adanya perencanaan kegiatan, perencanaan alat, serta perencanaan bahan (2009: 304); 2) organizing (pengorganisasian) di SMPN 3 Sumenep melibatkan kepala sekolah, kepala laboratorium yang ditunjuk merupakan guru IPA, laboran yang merangkap sebagai teknisi reparasi alat dalam keadaan rusak ringan, pengelola laboratorium/ seluruh guru IPA di SMPN 3 Sumenep; 3) actuating (pelaksanaan) di SMPN 3 Sumenep adalah guru IPA yang berkolaborasi dengan laboran; dan 4) controlling (pengawasan) dilakukan dengan melibatkan seluruh pengguna laboratorium, mulai dari kepala sekolah sampai dengan siswa yang menggunakan laboratorium yang tersusun dalam struktur organisasi laboratorium, Robbins dan Coulter dalam Senta (2014) menyatakan bahwa fungsi controlling adalah untuk menjamin agar segala sesuatu berjalan sebagaimana mestinya, para pengelola harus memantau dan mengevaluasi kinerjanya.

Bafadal (2009) menjelaskan salah satu tujuan manajemen sarana dan prasarana pendidikan yaitu untuk mengupayakan pengadaan sarana dan prasarana pendidikan melalui sistem perencanaan dan pengadaan secara hati-hati dan saksama, sehingga sekolah atau madrasah memiliki sarana dan prasarana yang baik sesuai dengan kebutuhan dana yang efisien. Proses perencanaan dan pengadaan lebih efisien jika disesuikan dengan kebutuhan dan tepat guna yang diperoleh dari kontribusi yang optimal dari pejabat yang berperan aktif dan arsip yang baik yang tergambar dalam struktur organisani dan kegiatan administrasi yang jelas. Manajemen yang masih belum baik sebaiknya lebih ditingkatkan lagi, secara keseluruhan manajemen laboratorium IPA SMPN 3 Sumenep sudah baik karena selalu melibatkan seluruh warga sekolah. Krajcik dan Banaszak Holl. (2012), menyebutkan bahwa salah satu prasyarat dalam pembelajaran/praktikum IPA adalah pemanfaatan laboratorium. Oleh sebab itu diperlukan adanya sistem pengelolaan atau manajemen laboratorium IPA yang baik. Hal senada dikemukakan oleh Berte (2012), bahwa pengelolaan laboratorium memiliki peranan penting dalam mewujudkan efektivitas pembelajaran.

Kesesuaian Standardisasi Laboratorium IPA SMPN 3 Sumenep dengan PERMEN 24 tahun 2007

Instrumen pertama mengobservasi ketersediaan faktor perencanaan laboratorium IPA, berdasarkan Sumarjono (1999) perlu memperhatikan faktor limbah, keamanan dan 
kenyamanan, sumber listrik PLN, dan sumber air. Faktor limbah bertujuan untuk memisahkan antara limbah padat, cair, dan gas. Di Laboratorium IPA SMPN 3 Sumenep faktor limbah masih belum tersedia dengan baik, sehingga limbah dari kegiatan laboratorium masih tercampur. Tempat sampah yang tersedia hanya tempat sampah umum yang letaknya dekat dengan laboratorium. Faktor keamanan dan kenyaman di Laboratorium IPA SMPN 3 Sumenep cukup memadai, hal ini terlihat dari adanya kipas angin sehingga menjaga kenyamanan peserta didik agar tidak kepanasan pada saat melakukan kegiatan laboratorium. Faktor keamanan sudah ada namun belum maksimal sehingga perlu dilengkapi karena kecelakaan dapat terjadi saat kegiatan laboratorium tanpa diduga.

Faktor sumber listrik PLN sudah dilengkapi dengan baik di Laboratorium IPA SMPN 3 Sumenep serta dilengkapi pengaman listrik (sekring) jika terjadi korsleting listrik. Tidak semua kegiatan laboratorium menggunakan air, akan tetapi sumber air perlu juga disiapkan untuk mendukung kegiatan laboratorium yang berhubungan dengan air, baik untuk mencuci tangan, mencuci alat percobaan, ataupun untuk digunakan sebagai bahan percobaan. Pembangan faktor sumber air di Laboratorium IPA SMPN 3 Sumenep sudah direncanakan dengan baik, namun perencanaan saja tidak cukup. Faktanya tempat sumber air ada namun tidak dapat digunakan sesuai fungsinya, karena air tidak bisa mengalir dari tempat sumber air.

Ketersediaan faktor perencaan laboratorium IPA seharusnya terdapat lima faktor (Sumarjono, 1999), dari lima faktor tersebut yang tersedia ada tiga faktor yaitu faktor keamanan dan kenyamanan, serta sumber listrik PLN. Sehingga dapat disimpulkan bahwa 60\% sudah memenuhi pemikiran dan perencanaan laboratorium IPA yang baik/ ideal (Istiqomah dan Kusumaningtyas, 2016).

Lembar instrumen observasi kedua mengamati kriteria laboratorium IPA SMP, berdasarkan PERMEN No 24 Tahun 2007 harus memiliki enam ruang yaitu ruang: 1) kegiatan belajar mengajar; 2) persiapan; 3) gudang; 4) gelap; 5) timbang; dan 6) kaca. Ruang kegiatan belajar mengajar di Laboratorium IPA SMPN 3 Sumenep memiliki lebar 7 meter melebihi rasio lebar minimum yaitu $5 \mathrm{~m}$, luas ruangan adalah $56 \mathrm{~m}^{2}$ hal ini juga melebihi rasio luas minimun yaitu $48 \mathrm{~m}^{2}$, ruang kegiatan belajar mengajar idealnya $2,4 \mathrm{~m}^{2} /$ peserta didik namun di laboratorium SMP Negeri 3 Sumenep hanya 2,25 $\mathrm{m}^{2}$. Dari hal itu dapat diketahui bahwa Laboratorium IPA SMP Negeri 3 Sumenep belum sesuai dengan standar sarana dan prasarana SMP berdasarkan PERMEN 24 tahun 2007. Ketidak sesuaian ini dikarenakan lahan untuk pembangunan laboratorium kurang memadai sehingga hanya tercapai $2,25 \mathrm{~m}^{2} /$ siswa. Dapat dikatakan laboratorium ini sudah cukup baik karena hampir mendekati standar laboratorium yang ada.

Ruang gudang digunakan untuk menyimpan barang-barang yang belum digunakan. Fungsi dari ruang gudang sudah sesuai dengan PERMEN 24 tahun 2007. Ruang gudang diisi dengan lemari dan rak, ukurannya adalah $7 \mathrm{~m} \times 3 \mathrm{~m}=21 \mathrm{~m}^{2}$ yang melebihi ukuran minimum yaitu $4 \mathrm{~m} \times 5 \mathrm{~m}=20 \mathrm{~m}^{2}$. Dari kriteria laboratorium IPA dengan enam ruangan berdasarkan PERMEN 24 tahun 2007 hanya terdapat dua ruangan saja di laboratorium SMP Negeri 3 Sumenep, yang berarti bahwa 33,3\% sudah memenuhi standardisasi sarana dan prasarana laboratorium IPA. Persentase kriteria laboratorium menunjukkan penilaian tidak baik/ tidak ideal sehingga perlu tambahan rencana untuk meningkatkan nilai persentase sehingga laboratorium IPA SMPN 3 Sumenep menjadi laboratorium IPA SMP yang ideal.

Rasio luas minimum ruang laboratorium $48 \mathrm{~m}^{2}$ dengan lebar ruang laboratorium IPA minimum $5 \mathrm{~m}$. Laboratorium IPA SMPN 3 Sumenep memiliki luas $52 \mathrm{~m}^{2}(8 \mathrm{~m} \times 7 \mathrm{~m})$, dengan demikian dapat disimpulkan bahwa rasio laboratorium sudah sesuai dengan rasio minimum ruang laboratorium pada PERMEN No 24 Tahun 2007. Selain itu Ruang laboratorium IPA SMPN 3 Sumenep memiliki fasilitas yang memungkinkan pencahayaan memadai untuk membaca buku dan mengamati obyek percobaan seperti pada Gambar 3.

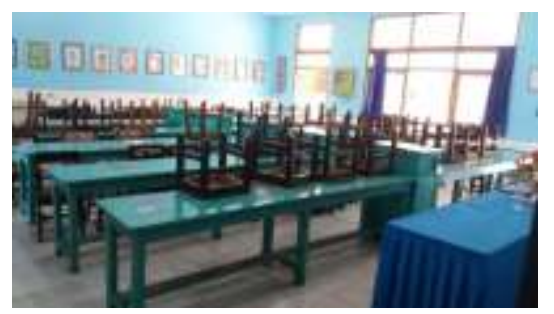

Gambar 3. Pencahayaan Laboratorium IPA SMPN 3 Sumenep Memadai 
Instrumen ketiga digunakan untuk observasi jenis dan rasio perlengkapan laboratorium meliputi kategori perabot, peralatan, media pendidikan, dan perlengkapan lainnya. Rata-rata persentase perlengkapan laboratorium IPA SMPN 3 Sumenep sebesar $86,34 \%$ dengan kriteria baik/ ideal dan sesuai dengan standardisasi PERMEN No. 24 tahun 2007. Rincian kesesuaian standardisasi laboratorium IPA SMPN 3 Sumenep terdapat pada Tabel 5.

Tabel 5. Standardisasi Laboratorium IPA SMPN 3 Sumenep

\begin{tabular}{lcc}
\hline \multicolumn{1}{c}{ Instrumen } & $\begin{array}{c}\text { Persen } \\
\text { tase }\end{array}$ & Kriteria \\
\hline $\begin{array}{l}\text { Ketersediaan } \\
\text { faktor-faktor } \\
\text { perencaan lab IPA }\end{array}$ & 60 & Baik/ ideal \\
\hline $\begin{array}{l}\text { Kriteria } \\
\text { laboratorium IPA }\end{array}$ & 33,3 & $\begin{array}{l}\text { Tidak baik/ } \\
\text { tidak ideal }\end{array}$ \\
\hline $\begin{array}{l}\text { Jenis dan rasio } \\
\text { perlengkapan } \\
\text { laboratorium IPA }\end{array}$ & 86,34 & Baik/ ideal \\
\hline \multicolumn{1}{c}{ Rata-rata } & $\mathbf{5 9 , 8 8}$ & Baik/ideal \\
\hline
\end{tabular}

Tabel 5. menunjukkan hasil 59,88\% yang artinya secara keseluruhan Laboratorium IPA SMP Negeri 3 Sumenep merupakan laboratorium yang baik/ ideal (Istiqomah dan Kusumaningtyas, 2016) untuk Laboratorium IPA SMP serta sudah memenuhi standardisasi berdasarkan PERMEN No. 24 tahun 2007.

\section{KESIMPULAN}

Dari hasil penelitian yang telah kami lakukan, kami menyimpulkan bahwa perlengkapan dan manajemen laboratorium IPA SMPN 3 Sumenep memiliki persentase $86,34 \%$ dengan kriteria baik / ideal dan sudah sesuai dengan standardisasi PERMEN No. 24 tahun 2007.

\section{DAFTAR PUSTAKA}

Arikunto, Suharsimi \& Yuliana, Lia. 2009. Manajemen Pendidikan. Cetakan ke-5. Yogyakarta: Aditya Media.

Bafadal, Ibrahim. 2009. Manajemen Perlengkapan Sekolah, Teori \& Aplikasinya. Jakarta: PT Bumi Aksara.
Berte, L.M. 2012. Quality Management System: A Model for Laboratory Services; Approved Guideline. Fourth Edition. Clinical and Laboratory Standards Institute.

Badan Standar Nasional Pendidikan. 2010. Laporan BSNP Tahun 2010.

Darsana, I Wayan., Sadia, I Wayan., dan Tika, I Nyoman. 2014. Analisis Standar Kebutuhan Laboratorium Kimia Dalam implementasi Kurikulum 2013 pada SMA Negeri di Kabupaten Bangli. EJurnal Program Pascasarjana Universitas Pendidikan Ganesha. Volume 4.

Istiqomah, Hanin Fathan Nurfina., dan Kusumaningtyas, Dian Artha. 2016. Analisis pengelolaan peralatan praktikum fisika kelas XI SMA Muhammadiyah 1 Yogyakarta menggunakan model countenance stake. JRKPF UAD.Vol.3 No.1

Krajcik, J. S. and Banaszak Holl, M. M. 2012. Concurrent Enrollment in Lecture and Laboratory Enhances Student. Journal of Research in Science Teaching. Vol 49 Issue 5.

Mulyono. 2008. Manajemen Administrasi dan Organisasi Pendidikan. Yogyakarta: ArRuzz Media.

Peraturan Pemerintah RI, No 19 Tahun 2005. Tentang standar nasional pendidikan.

Permendiknas No 24 Tahun 2007. Tentang standar sarana dan prasarana disekolah.

Satori, Djam'an., dan Komariah, Aan. 2009. Metodologi Penelitian Kualitatif. Bandung: Alfabeta.

Senta, Putri. 2014. Pengelolaan Laboratorium IPA Studi di SMP Negeri 80 Jakarta Timur. Jurnal Manajemen Pendidikan. 3(2):194-210

Sumarjono. 1999. Pengelolaan Laboratorium IPA: Bahan Pelatihan Manajemen Pendidikan Bagi Kepala SMU SeIndonesia di Malang. Malang: Jurusan Fisika FMIPA UM.

Yuliarty, P., Permana, T., \& Pratama, A. 2008. Pengembangan Desain Produk Papan Tulis dengan Metode Quality Function Deployment (QFD). Jurnal Ilmiah PASTI. Volume VI Edisi 1. 